\title{
Gümüşhane Rum Erkek Okulu'nun Sanat Tarihi ve Tasarımı Açısından Değerlendirilmesi
}

\author{
Nurgül Şentürk ${ }^{1}$, Mahmut Sarı ${ }^{2 *}$ \\ ${ }^{1}$ Gümüşhane Üniversitesi, Gümüşhane M.Y.O, Tasarım Bölümü, Gümüşhane, Türkiye, (ORCID: 0000-0003-4222-7265), nurgul.senturk@gumushane.edu.tr \\ ${ }^{2 *}$ Gümüşhane Üniversitesi, Gümüşhane M.Y.O, İnşaat Bölümü, Gümüşhane, Türkiye (ORCID: 0000-0002-1006-6332), msari@gumushane.edu.tr
}

(Uluslararası Araştırma-Geliştirme ve Tasarım Konferansı - 15-18 Aralık 2021)

(DOI: 10.31590/ejosat.1039451)

\begin{abstract}
ATIF/REFERENCE: Şentürk, N. \& Sarı, M. (2021). Gümüşhane Rum Erkek Okulu'nun Sanat Tarihi ve Tasarımı Açısından
\end{abstract} Değerlendirilmesi. Avrupa Bilim ve Teknoloji Dergisi, (32), 770-775.

\section{$\ddot{O} \mathbf{z}$}

Gümüşhane; Trabzon Rum İmparatorluğu'nun 1461 yılında fethedilmesinden sonra Osmanlı Devleti hâkimiyetine girerek, farklı etnik grupların faaliyet gösterdiği bir şehir haline gelmiştir. I. Dünya Savaşı yıllarında Doğu Karadeniz'de aktif olarak rol oynayan Rum ve Ermenilerin, Trabzon ve çevre illerde birçok kamu yapısı inşa ettiği görülmektedir. Halk arasında 'Sarı Mektep' olarak bilinen Gümüşhane Rum Erkek Okulu; genişleyen Süleymaniye Mahallesi içerisinde, kuruluşundan günümüze değin birçok farklı amaçla kullanılmış ve siluetini büyük ölçüde korumuştur. Bu çalışmada; Gümüşhane Rum Erkek Okulu, mimarlık, sanat tarihi ve tasarım özellikleri bakımından incelenecek, yapının bilinmeyen yönleri aydınlatılarak, sürdürülebilirliği incelenip, araştırmacılar ve kültür mirası açısından gelecek nesillere aktarılmasının önemi üzerinde durulmuştur. Yapının Eski Gümüşhane'ye hâkim bir noktada; alışlagelmiş dikdörtgen plan tipinde, simetrik ve sade bir düzende inşa edildiği tespit edilmiştir. Ayrıca, zemininde ve çevresinde yapılan saha gözlemleri ile okulun zemininde çökmeler meydana geldiği ve buna bağlı olarak zamanla çeşitli onarımlar geçirmek zorunda kaldığı belirlenmiştir. Bu tip nitelikli kültür varlıklarımızın korunarak ve restöre edilerek günümüze kazandırılmasına önem gösterilmelidir.

\section{Evaluation of Gümüşhane Greek Boys' School in terms of Art History and Design}

\begin{abstract}
Gümüşhane came under Ottoman rule after conquering the Greek Empire of Trabzon in 1461, operating differently. It is seen that Greeks and Armenians, who played an active role in the Eastern Black Sea Region during World War I, built many public buildings in Trabzon and the surrounding provinces. Gümüşhane Greek Boys' School, popularly known as the 'Yellow School'; in the expanding Süleymaniye District, it has been used for many different purposes since its establishment and has largely preserved its silhouette. This study examined the Gümüşhane Greek Boys School in terms of architecture, art history, and design features, illuminated the unknown aspects of the building, challenged its sustainability, and emphasized the importance of transferring it to future generations. At a point that dominates the Old Gümüşhane; It has been determined that it was built in the usual rectangular plan type, in a symmetrical and simple order. In addition, with the field observations made on the ground and its surroundings, it was determined that the school's bottom had collapsed. Accordingly, it had to undergo various repairs over time. It should pay attention to preserving and restoring such qualified cultural assets and bringing them to the present day.
\end{abstract}

Keywords: Greek School, Art History, Architectural Design. 


\section{Giriş}

Halk arasında Sarı Mektep adıyla bilinen Rum Erkek Lisesi; Süleymaniye Mahallesi (Eski adıyla Hızırilyas/Agios Georgios Mahallesi) sınırları içerisinde yer almakta olup, yapı konum itibariyle kente hâkim durumdadır. Mektep, 1723 yılında Kaloyerandon Konağı içerisinde kurulmuş olsa da eski yerleşim yeri hakkında bilgi bulunamamıştır (Dolu, 2010) Kaynaklara göre okulun inşası; 8 Temmuz 1875 yılında başlamış ve dört yıl süren inşaat 1879 yılında tamamlanmıştır (Şekil 1). Okul bitirildiği tarihte eğitim-öğretim faaliyetlerine başlamıştır. Yapının kitabesine ulaşılamadığından, banisi ve mimarı hakkında kesin bir bilgi verilememektedir.

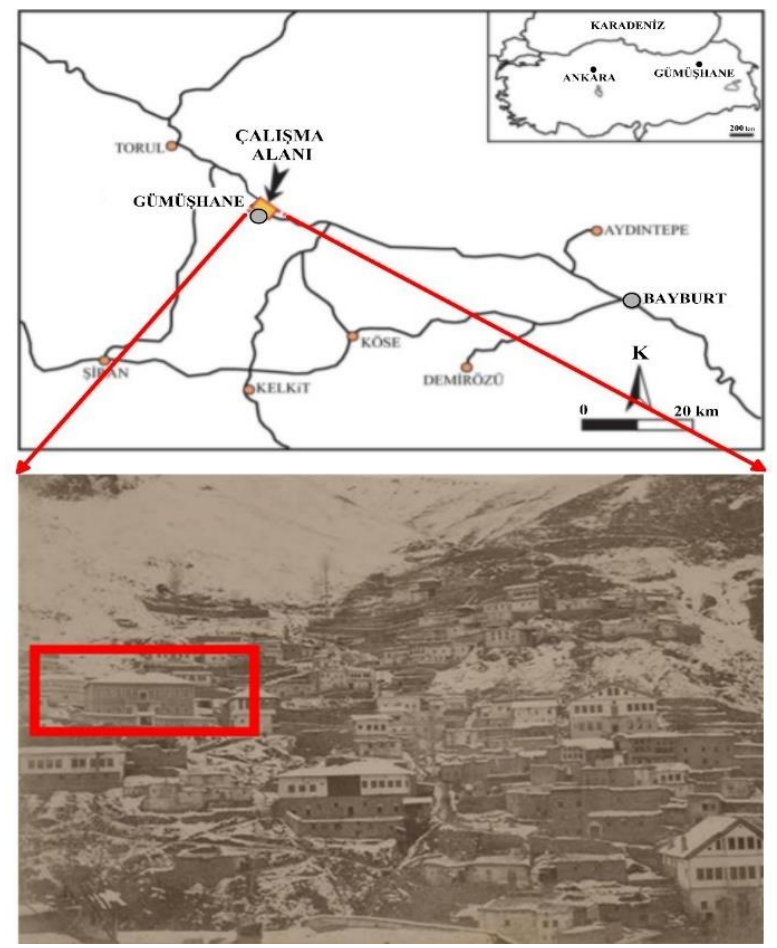

Şekil 1: Rum Erkek Lisesi 19. Yüzyıl Başı Genel Görünümü (İstanbul Eski Eserler Kütüphanesi, Yıldız Albümleri Arşivi) ve yer buldur haritası

1855-1860 yılları arasında okul müdürünün Georgios Papadopoulos Kiriakidis olduğundan bahsedilmektedir (Dolu, 2010). Georgios, Sumelidis gibi okulun kuruluşunda ve eğitim hayatında rol oynayan önemli şahsiyetlerden biridir. Yap1 eğitim tarihinde gayrimüslim okulları içerisinde geniş kapsamlı bir okul olmuştur. Okul bünyesinde; 1 ilkokul, 3 orta okul, 5 lise sınıfi, 20 'ye yakın öğretmen ve yaklaşık 300 öğrenci bulunduğu belirtilmektedir.

Okul; 1723 yılından eğitime basit bir okuma yazma okulu olarak başlamış, 1836'da Allilodidaktiko seviyesinde bir erkek okulu olarak faaliyetine devam etmiştir. Okul bünyesine 1864 'de bir syndidaktiko sınıfı eklenmiş, $1878^{\prime}$ de ise yarı lise (İmigymnasio) düzeyinde eğitime geçilerek sürekli kurum sürekli değişime uğramıştır (Kolektif, 2019).

Okul binası I. Dünya Savaşı döneminde 1918 yılına kadar eğitim hizmeti vermiş, bu dönemde Türk hükümeti tarafindan kapatılarak askeri hastane olarak kullanılmaya başlanmıştır. Savaş sonrasında metruk olarak varlığını sürdüren yapı, zamanla özel şahısların mülkiyetine geçmiştir (URL-1). Yapı günümüzde;
Erzurum KTVKK'nın 24.06.1989 gün ve 160 sayılı kararı ile tescil edilmiş ve Gümüşhane'nin taşınmaz kültür varlıkları içerisindeki yerini almıştır.

\section{Materyal ve Metot}

\subsection{Bulgular ve Mimari Özellikler}

Okul binası günümüzde, Süleymaniye Mahallesi'nde ana arter üzerindeki yerleşim yerinin güneyinde yer almaktadır. Yapı; 314 ada 1 parsel numaralı alan üzerinde konumlandırılmıştır. Okulun bulunduğu arazi, daha evvel özel mülkiyete aitken sonrasında devlet tarafından satın alınmıştır (Şekil 2).

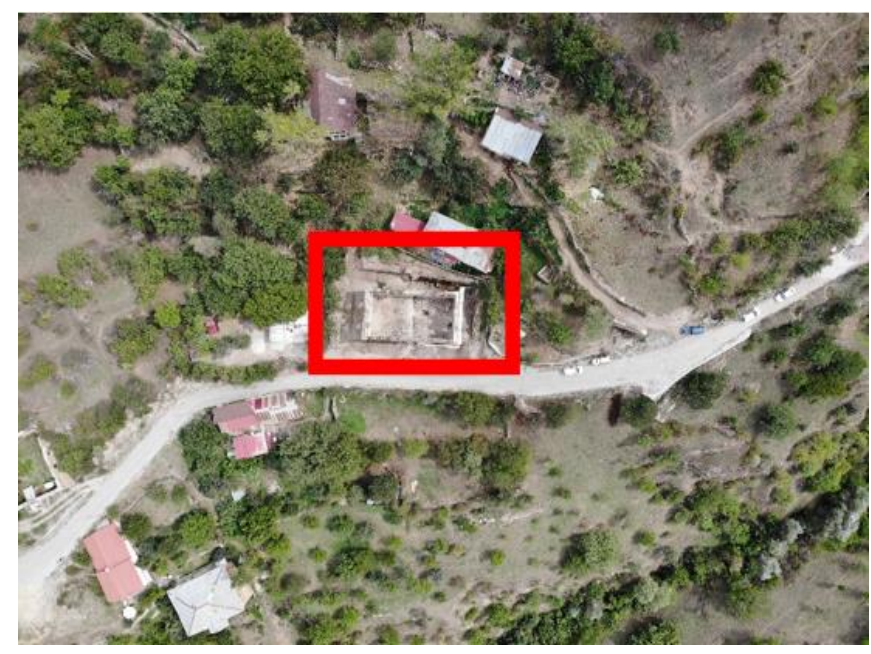

Şekil 2: Rum Erkek Okulu drone görüntüsü

Eski Rum Erkek Okulu'nun 19. yy. dönemine ait fotoğraflarına bakıldığında, yapı ana yol üzerinde dar bir avlu içerisinde yer almakta ve arka kısmında okul öğretmenleri tarafından kullanıldığı öngörülen iki katlı bir ev yer bulunmaktadır. Yapının ilk inşasında; avlu dört yönden hartama örtülü moloz taş duvarlarla çevrilmiş olup, avluya giriş Kuzeydoğu cephesindeki dikdörtgen biçimli sade bir taş kap1 aracılığı ile sağlanmıştır (Şekil 1). Avlu giriş kapısı, okulun ana girişinin tam karşısına yerleştirilmiştir. Günümüzde; Kuzeydoğu (Giriş Cephesi) yönündeki avlu duvarı tamamen yıkılmış, diğer yöndekiler ise kısmen ayakta kalmıştır. Yapının eğimli bir arazi üzerine inşa edilmesi, zemin hizasında her cephede kot farkl1lıkları meydana getirmektedir.

\subsubsection{Yapının Plan Özellikleri}

Yapının planı ve biçimlenişi; Trabzon, Giresun gibi çevre illerde inşa edilen Rum okullarından çok farklı bir düzene sahip olup, Eski Gümüşhane'de inşa edilen birtakım kamu yapıları (Metropolithane, Eski K1z Okulu vb.) ile benzerlik göstermektedir (Geçgil, 2016). Okul; kuzey-güney doğrultusunda, 18,30 x 11,28 m ölçülerinde dikdörtgen bir plan üzerine yerleştirilmiştir (Şekil 3). Dışarıdan bakıldığında zemin kat ile beraber 2 katlı olarak inşa edilen yapının üzeri eski fotoğraflarda görüldüğü gibi ahşap strüktür üzerine kırma çatı ile örtülmüştür (Düzgün-Çalık, 2017). Yapının üzeri inşa edildiği dönemde bölgeye özel geleneksel olarak yapılan, ince ahşap plakaların eğimli dizilmesiyle oluşturulan hartama çatı ile 
örtülmüştür (Sözen-Tanyeli, 2014). Okulun çatı katı maalesef günümüze ulaşamamıştır (Şekil 1).

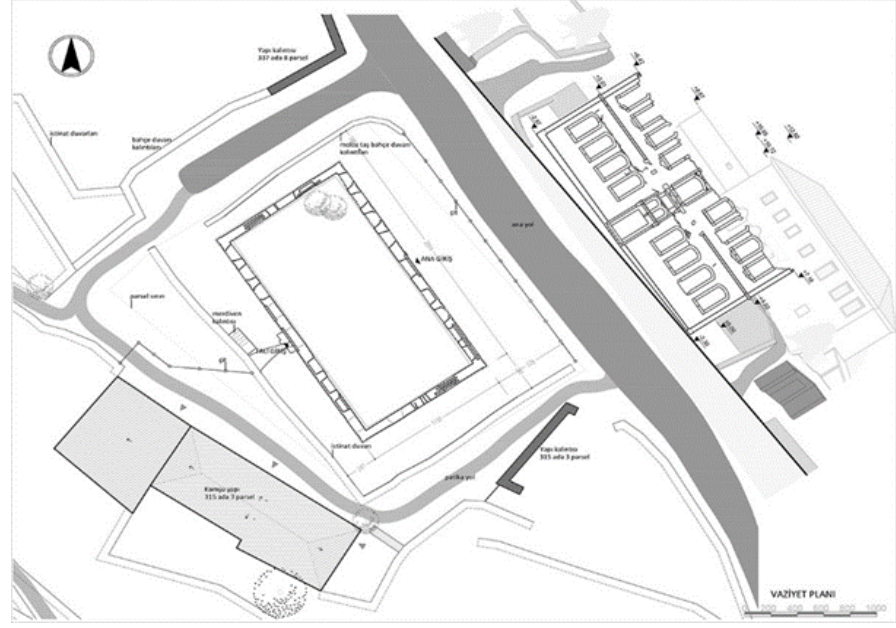

Şekil 3: Rum Erkek Okulu Vaziyet Planı (URL-2)

\subsubsection{Yapının Cephe Tasarımı}

Yapının beden duvarlarında karışık derzli moloz taş malzeme kullanılmıştır. Cephelerin kenarlarında ise dikdörtgen düzgün kesme taş kullanılarak, köşebentler oluşturulduğu görülmektedir. Köşebentlerde kullanılan taş türü, kat silmelerinde ve pencere kenarlıklarında daha küçük boyutlu olarak devam ettirilmiştir. Yapının beden duvarlarında taş malzeme haricinde; bağlayıcı olarak ahşap hatıllara ve güçlendirici demir gergilere yer verilmiştir. Okul pencere ve kapılarında ise günümüze ulaşamayan ahşap malzemelerin kullanıldığı görülmektedir.

Okul binasına giriş kuzeydoğuya bakan cepheden sağlanmaktadır (Şekil 4). Kuzeydoğu cephesi zeminde yaklaşık 57 cmlik bir eğim oluşturmaktadır. Cephe, giriş kapısının her iki yönünde simetrik olarak düzenlenmiştir. Bu simetrik düzenin, yapının her cephesinde devam ettirildiği görülmektedir. Kuzeydoğu cephesinin yüzeyi, giriş kapısının karşı yönünden bakıldığında sol tarafından dışa doğru çıkıntı oluşturmaktadır. Yapının eski görselleri, bu bölümün balkon çıkmasını desteklemek amacıyla öne çekildiği fikrini desteklemektedir. Bu öne çekilmiş bölüm hem planda hem duvar yüzeyinde az da olsa simetrik akışın bozulmasına neden olmuştur.

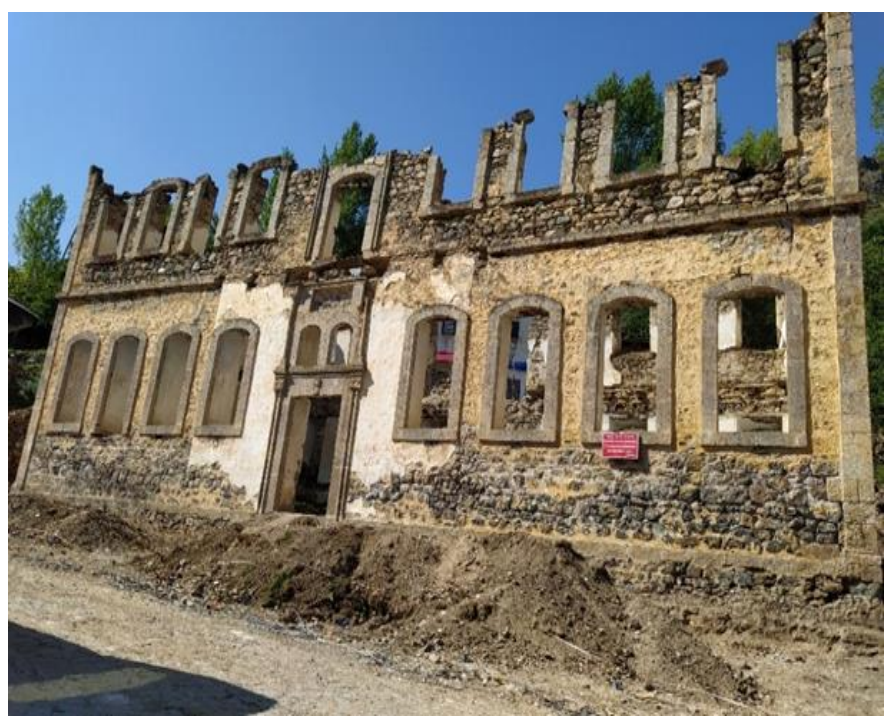

Şekil 4: Rum Erkek Okulu Ana Giriş Cephesi Genel Görünümü
Yapının giriş kapısı birinci kat silmesine kadar uzanmakta olup, dikdörtgen biçimli bir görünüme sahiptir. Kapı zeminden yükseğe inşa edildiğinden, eşik ile zemin muhtemelen birkaç basamaklı bir merdiven birbirine bağlanmıştır. Tam orta aksta iki katlı olarak düzenlenen giriş kapısı; her üç yönden dikdörtgen kesme taşlar ile sınırlandırılmıştır. Dış kapıya ait taş sövelerin içe bakan yüzeylerinde kapı kanatlarına ait demir bağlantı elemanları kullanılmıştır. Bu bilgiden hareketle kapının ahşap malzemeden yapıldığı ve iki kanatlı olduğu düşünülmektedir (Kolektif, 2019). Yapının dış mekânında tezyinat yalnızca bu orta aksta karşımıza çıkmaktadır (Şekil.5).

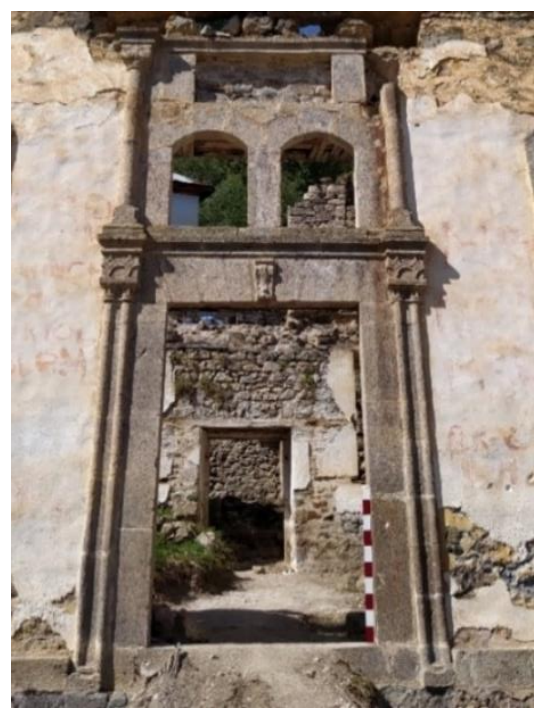

Şekil 5: Rum Erkek Okulu Ana Giriş Kapısı

Kapının her iki yanında, ikiz korint başlıklı ince sütunceler bulunmaktadır. Sütunceler, dışa taşkın iki adet düşey yiv ile hareketlendirilmiş, kemer üzengilerinin yüzeyine iki adet dört kollu yıldız motifi konulmuştur (Şekil 6.a). Kapı üzerindeki düz kemerin ortasında yer alan kilit taşında, barok stildeki süslemeleri hatırlatan bir rozet yer almaktadır (Şekil 6.b) Kapı üst sövesinin hemen üzerinde ise; küçük boyutlu, yuvarlak basık kemerli ikiz pencere açıklığı yer almaktadır. Günümüzde, dönem fotoğraflarında görülen ahşap iki kapaklı pencereler yerinde bulunmamaktadır. Pencerelerin hemen üzerinde üzerinde yapıya ait dikdörtgen kitabelik yer almaktadır. Fakat yapının inşa kitabesi günümüzde bulunamadığından; okulun banisi, mimarı hakkında kesin bir bilgi elde edilememektedir. Kitabelik ve pencerelerin bulunduğu alan; her iki yönde iyon başlıklı silindirik sütunceler, en üstte ise yatay silmelerin oluşturduğu taş söve ile sınırlandırılmıştır (Şekil 6.c)
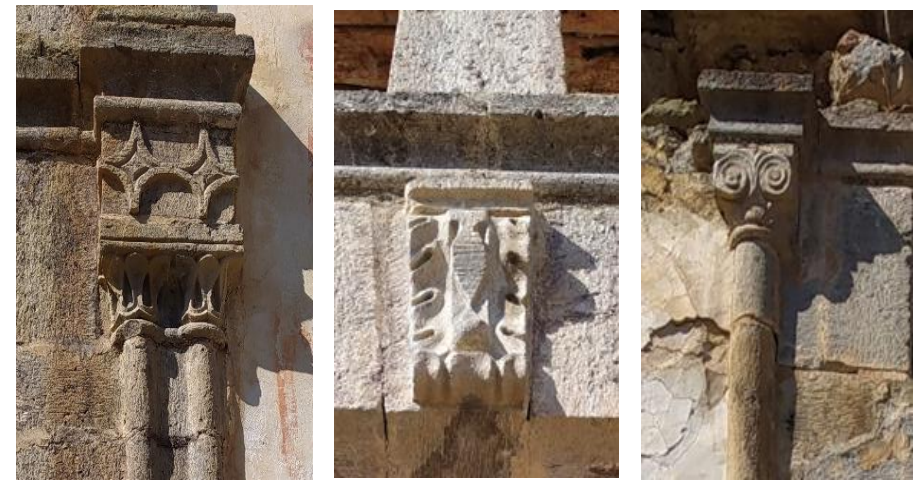

Şekil 6: a) Alt Sütunce Süslemesi b) Kilit Taşı Süslemesi c) Üst Sütunce Süslemesi 
Yapının zemin katında, giriş kapısının sağında ve solunda dörder tane olmak üzere toplamda 8 adet yaklaşı 192 x $150 \mathrm{cmlik}$ dikdörtgen pencere açıklığı yer almaktadır. Cephenin birinci kat hizasına, kapının tam üzerine denk gelecek şekilde bir balkon çıkması yerleştirilmiştir. Balkon dikdörtgen biçimli bir alana sahip olup, çevresi demir trabzanlarla çevrilmiştir. Balkona çıkış iki kapaklı, yuvarlak basık kemerli ahşap bir kapıdan sağlanmıştır. Birinci katta da balkonun sağında ve solunda toplamda 8 adet düzgün kesme taştan yapılmış pencere açıklığı bulunmaktadır. Dönem fotoğraflarından, zemin kat pencereleri gibi burada da iki kanatlı pencerelerin kullanıldığı görülmektedir. Zemin kat pencere kayıtları; düşeyde dört, yatayda iki bölmeli olarak yapılmıştır. Pencere kayıtları birinci kat hizasında ise; yatayda iki düşeyde üç bölmeli olarak düzenlenmiştir. Eski fotoğraflarda karşımıza çıkan bu beyaz ahşap pencereler ne yazık ki günümüze ulaşamamıştır. $\mathrm{Bu}$ ahşap elemanların binadan sökülerek farklı yerlerde devşirme malzeme olarak kullanıldığg düşünülmektedir.

Yapının kuzeybatı ve güneydoğu cepheleri birbiriyle tıpatıp benzerlik göstermektedir. Her iki cephede de zemin katta, iki adet yuvarlak basık kemerli pencere açıklığı yer almaktadır. Cepheler, tüm yapıyı dolanan kat silmesi ile iki yatay bölüme ayrılmıştır. Birinci kat hizasında alt kat pencereleri aynı düzende devam ettirilmiştir ve yine 2 adet pencere kullanılmıştır (Şekil 7).

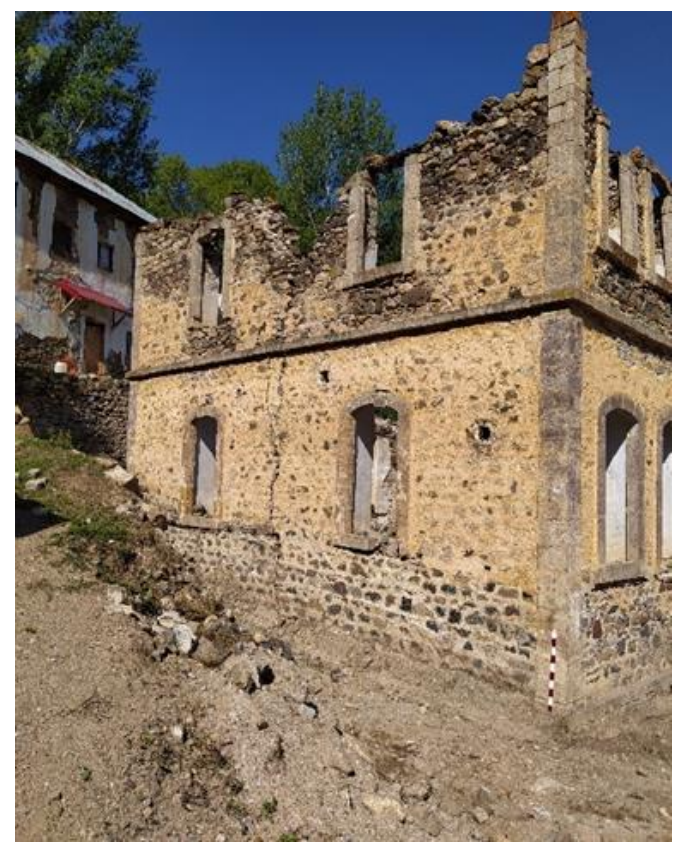

Şekil 7: Rum Erkek Okulu Güneydoğu Cephesi

Bu cephelerin her ikisinde tam ortada bulunan yapının zaman içerisinde aldı ̆̆ 1 hasarlar ve zemin çökmeleri nedeniyle oluşan derin çatlaklar bulunmaktadır. Okul binasının yan cephelerinde süslemeye rastlanmamıştır. Cephelerde sayısı hakkında kesin bilgi veremediğimiz çörten yuvaları görülmektedir (SözenTanyeli, 2014). Cephelerin çatıya yakın yüzeyleri, ana giriş yönünde olduğu gibi günümüzde yıkılmış vaziyettedir. Cephelerin yüzeyleri okulun bütün beden duvarlarında olduğu gibi sarı sıva kaplanmıştır (Şekil 8).

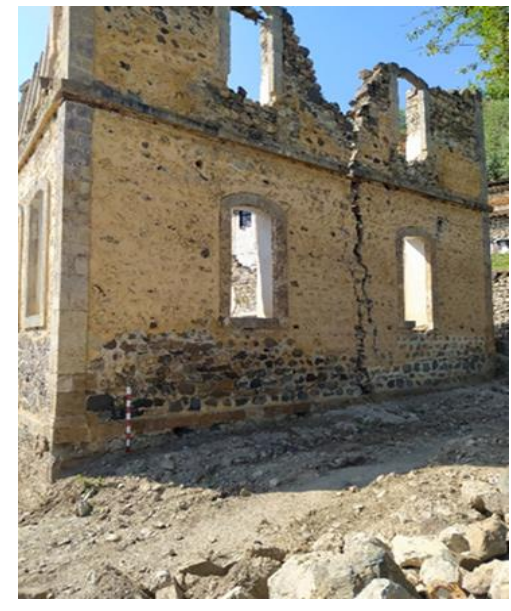

Şekil 9: Rum Erkek Okulu Kuzeybatı Cephesi

Okul binasının Güneybatı cephesi diğer cephelerden düzen açısından farklılık göstermektedir. Bu cephede; tek gözlü ve sivri kemerli bir taş köprü yer almaktadır. Köprü okul binasının ikinci kat hizasındaki kapıdan arka avluya bağlamaktadır. Köprünün bulunduğu zemine yapının çevresini dolanan tali yol ile ulaşılmaktadır. Daha evvelde belirtildiği üzere yapının zemin katı ve birinci katı arasında bir merdiven kalıntısı bulunmaması, köprünün yalnızca idareciler ve öğretmenler tarafından kullanıldığı ispatlamaktadır (Kolektif, 2019). Köprünün kesme taş korkulukları zamanla yıkılmış, günümüzde sadece kemer taşları kalmıştır. Burada aynı zamanda köprü hizasından başlayan ve istinat duvarına bitişik inşa edilen taş bir merdiven yer almaktadır. Merdivenler arka avludan binanın zemin kat hizasına inişi sağlamaktadır. Merdivenlerin günümüzde harap durumda olması ve üzerini toprak örtüsünün kapatması nedeniyle basamak sayısı hakkında bilgi verilememektedir (Şekil 9).

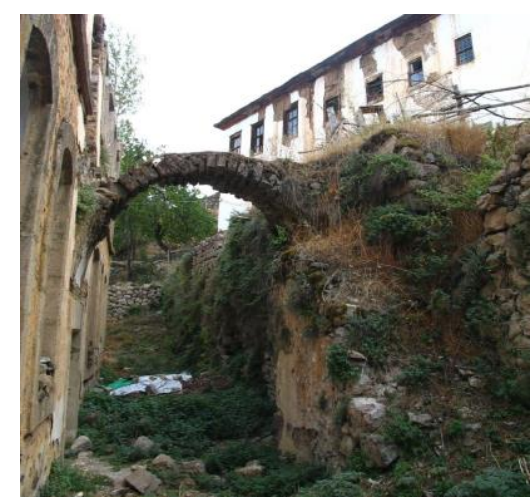

Şekil 9: Güneybatı Cephesi Köprü ve Merdiven Kalıntısı

Cephede zemin ve birinci katta olmak üzere toplamda iki adet kapı yer almaktadır. Kapılar dikdörtgen biçimli olup düz kemerlidir. Günümüzde ahşap kapılar yerinde bulunmamakta olup, üst kattaki taş kapı açıklığı da tamamen göçmüştür. Cephede; zemin katta kapının her iki yönüne yerleştirilmiş toplamda 8 adet yuvarlak basık kemerli pencere yer almaktadır. $\mathrm{Bu}$ pencereler nizami olarak birinci kat hizasında da devam ettirilmiş, yapı içerisinin aydınlık ve ferah olmasına olasına özen gösterilmiştir (Şekil 10). Bütün pencerelerin atkılarında; iç bölümde, ahşap hatıl dizilerinin üzerine bağdadi çıtaların kullanıldığı görülmektedir. 


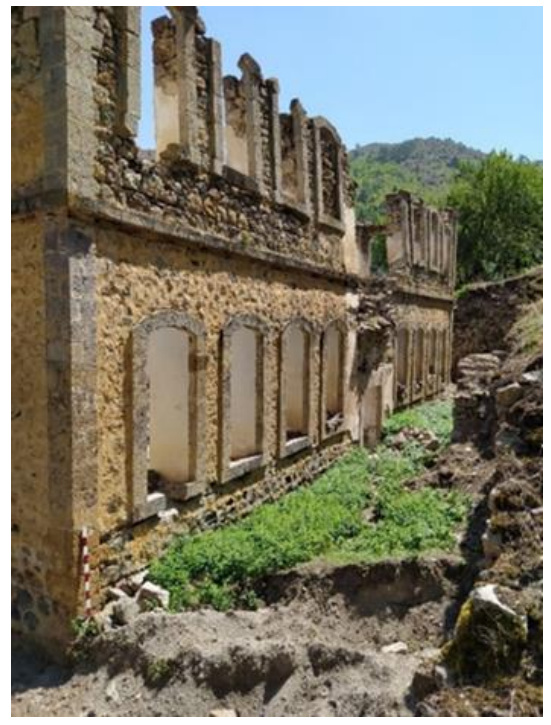

Şekil 10: Rum Erkek Okulu Güneybatı Cephesi Genel Görünümü

\subsubsection{Yapının İç Mekân Tasarımı}

Günümüzde yapının iç mekânına toprak ve taş dolduğu için, burada kullanılan yapı malzemesi, zemin döşemesi ve süslemeler hakkında kesin bir bilgi verilememektedir. Yapının iç mekânında günümüze ulaşan tek kalıntı; cephelerde görülen duvar bölmesi izleridir. Beden duvarlarının iç yüzeylerde sıva ile kaplanarak beyaz boya ile boyandığı görülmektedir. (Şekil.11). Bununla beraber çevre illerde yapılan Rum okullarının planları ve yapının restorasyon projesi incelendiğinde; okulun zemin katında, ana giriş kapısından güneybatı yönündeki kapıyı bağlayan bir hol ve bunun çevresine yerleştirilmiş 3 adet derslik yer almaktadır (Şekil.12).

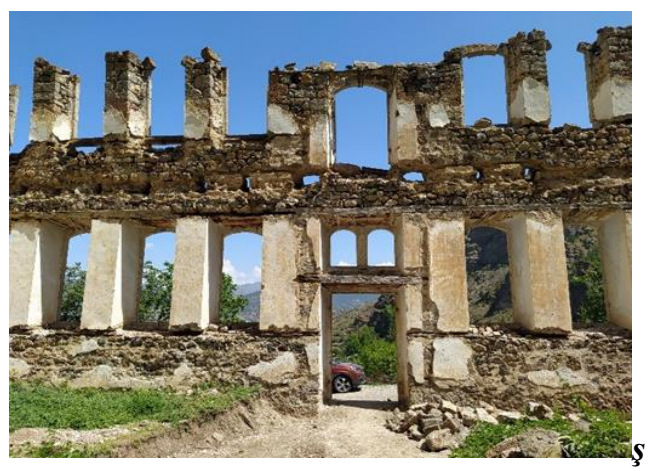

Şekil 11: Rum Erkek Okulu İç Mekânı Duvar Bölmesi İzleri

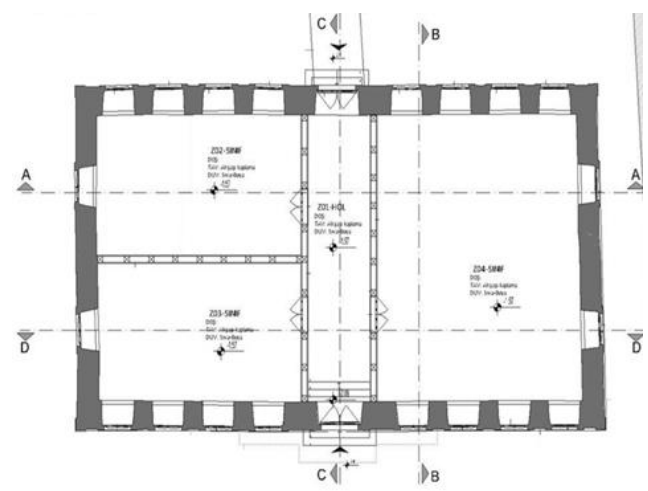

Şekil 12: Zemin Kat Restitüsyon Planı (Kolektif ,2016)
Okulun zemin katı ile birinci katı arasında herhangi bir merdiven kalıntısı bulunmamaktadır. Daha evvelde belirtildiği gibi, birinci kata giriş Güneybatı yönündeki kapıdan sağlanmıştır. Yapının birinci kat planı, muhtemel zemin kat planı ile benzerlik göstermektedir. Birinci kat düzeni balkon ve kapı arasında uzanan bir koridor ve her iki yönde yer alan odalardan meydana gelmektedir. Bu katta muhtemel plana göre toplamda 3 adet oda yer almaktadır. Yönetim katında yer alan odaların; müdür odası, öğretmenler odası ve kütüphane olarak kullanıldığ düşünülmektedir (Şekil.13). Okulun zemin ve birinci katında herhangi bir tuvalet kalıntısı izine rastlanmamıştır. Bu nedenle tuvaletlerin binanın avlusunda veya yakınlarında inşa edildiği düşünülmektedir. 2016 tarihli restitüsyon raporu araştırmaları; yapı ile benzer plana sahip olduğu düşünülen Hoskirasiye Okulu'nun avlusunda yapıdan bağımsı iki helanın bulunduğundan bahsetmektedir. $\mathrm{Bu}$ nedenle Rum Erkek Okulu'nda da kesin olmamakla birlikte, benzer bir uygulama yapıldığı düşünülmektedir. Konuyla ilgili kesin bilgilerin restorasyon kapsamında yapılacak olan kazı çalışmaları ile aydınlatılması beklenmektedir.

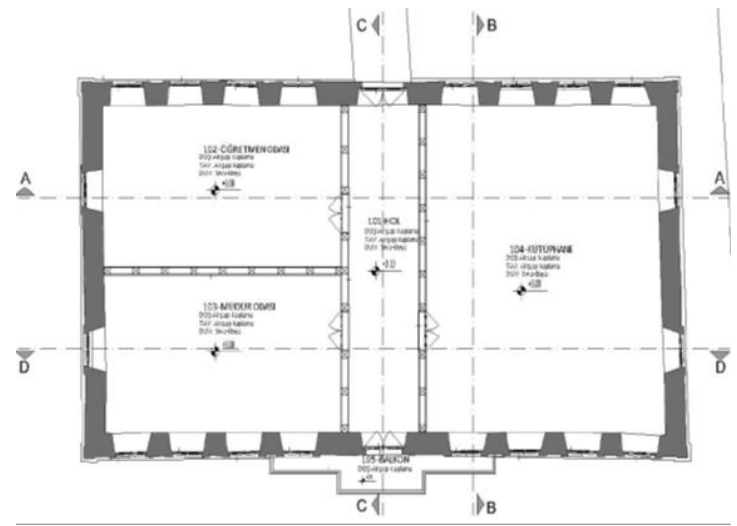

Şekil 13: Birinci Kat Restitüsyon Planı (Kolektif ,2016)

Yapının zemin döşemelerinde kalıntı izine rastlanmadığından net bir bilgi verilemezken, bu konuda çevrede inşa edilmiş yapıların iç mekân malzemeleri dikkate alınmıştır. Buna göre yapının hol bölümlerinin zemininde taş malzeme, odalarda ise ahşap döşemeye yer verildiği düşünülmektedir. Tavan ve duvar yüzeylerinde yer alabilecek süslemeler hakkında hiçbir bilgi bulunamamıştır.

Veri yetersizliği nedeniyle aydınlatılamayan bir diğer konu ise; yapı içerisinde katları birbirine bağşayan merdiven ögesine ait bir iz bulunamamasıdır. Merdivenlerin iç mekânda kullanılmaması okul bünyesinde idari kat ile öğrencilerin kullandığı sınıf bölimlerinin birbirinden bağımsız olarak düzenlendiği fikrini desteklemektedir.

\subsection{Tezyinat Programı}

Yapılan araştırmalar Gayrimüslim kamu yapıları içerisinde özellikle okul binalarının estetikden ziyade işlevsellik açısından ön plana çıkarıldığını göstermektedir.

Yapınının dış mekânında sadece ana giriş kapısı çevresinden süsleme ögelerine rastlanmıştır. Bu süsleme programının çok az ve sade olması dönem içerisinden taş işçiliğinin çok fazla gelişmediğini düşündürmektir. Yapının üzerinden Rum ve Ermeni mimarisinde karşımıza çıkan sembolik bir süslemeye rastlanmamış olup, tercih edilen mortifler ve düzenler Eski Yunan mimarisinin izlerini devam ettirmektedir. 


\section{Araştırma Sonuçları ve Tartışma}

Bu aşamaya kadar; Gümüşhane Rum Erkek Okulu ile ilgili mimari özellikler üzerinde durularak, yapının sanat tarihi ve tasarımı açısından dönem özellikleri açıklanmaya çalışılmıştır.

\subsection{Mekân Organizasyonunda Düzen}

Gayrimüslim eğitim yapılarında Trabzon ve çevre illeri dikkate alındığında; Gümüşhane Rum Erkek Okulu, bir koridor ve çevresine dizilmiş odalardan meydana gelen geleneksel Türk mimarisinde karnıyarık plan olarak adlandırılan bir tipoloji ile karşımıza çıkmaktadır. Yapının planında veri elde edilemeyen birtakım noktalar bulunmaktadır. Bu noktalardan birincisi yap1 içerisinde tuvalet ihtiyacını gideren bir bölüme rastlanmamamasıdır. Nereye konumlandırıldığı belli olmayan tuvalet alanlarının yapının çevresinde bir yere inşa edildiği düşünülmektedir.

\subsection{Zemin Özellikleri}

İnceleme alanında restorasyonu yapılacak Rum Okulu temeli yığma taşörme olarak inşa edilmiş olup, temel genişliği $1.2 \mathrm{~m}$, derinliği $2.5 \mathrm{~m}$ dikdörtgen kesitli ve duvar yükünü taşıyacak şekilde inşa edilmiştir. Dikdörtgen kesitin kısa kenarı 11.6m olup, uzun kenar $21.2 \mathrm{~m}$ dir. Bina restorasyonu tamamlandığ 1 zaman bina temelide dikkate alındığında temel altındaki zemine etki edecek gerilme miktarı yaklaşı $23 \mathrm{t} / \mathrm{m} 2$ olarak belirlenmiştir. Taşörme olarak inşa edilmiş yığma duvarlarda oluşan deformasyonların ise zeminden kaynaklı oturma probleminden kaynaklı olduğu düşünülmektedir.

\section{Sonuç}

Yapılan araştırmalar ve saha çalışmaları kapsamında; 'Sarı Mektep" adıyla anılan Eski Gümüşhane Rum Erkek Okulu'nun, 19. yüzyılda Trabzon Vilayetinde gayrimüslim okullar içerisinde önemli bir yer edindiğini göstermektedir. Okul yapısı; eğitimöğretim faaliyetlerine ilkokul, orta okul ve lise kademelerinde devam etmiş ve dönem içerisinde azınlıklar tarafından en çok kullanılan kamu yapılarından biri olmuştur.

Konum olarak Eski Gümüşhane olarak adlandırılan tepeye hâkim bir noktaya yerleştirilen yapı; çevre illerde ve Gümüşhane'de inşa edilen eğitim yapılarıyla benzer olarak dikdörtgen bir planda ve iki katlı olarak inşa edilmiştir. Okulun sadece beden duvarlarının yalnıza bir bölümü günümüze ulaşmıştır. Yapının çatı sistemi ve iç mekanına ait yapı elemanları zamanla tahrip edilmiştir. Yapının inşa veya onarım kitabesi günümüzde yerinde bulunmadığından banisi ve mimarı hakkındaki bilgiler yetersiz kalmaktadır.

Okul binasının içerisinde; katları birbirine bağlayan merdivenlerin bulunmaması, arka cephede yer alan köprüsü ve tuvalet alanlarının plan içerisine dahil edilmemesi mimarlık tarihinde alışılagelmiş geleneksel düzeni yıkması açısından önem arz etmektedir.

Araştırma neticesinde yapılan saha çalışmaları, çevre illerdeki benzer yapılar ve binanın tezyinat programı incelendiğinde; gayrimüslim kamu yapılarında genel olarak biçimden çok işlevselliğin ön plana çıktığı görülmektedir. Osmanlı mimarisinde alışılagelmiş olan estetik kavramının bir sonucu olan yoğun taş, alçı vb. süslemeler, gayrimüslim okul yapılarında geri planda tutulmuştur.

Okul binasının yapısal sistemi ve mimari çözümlemelerinde, yetersiz kalıntılar ve belgeler nedeniyle aydınlığa kavuşturulamayan birçok konu mevcuttur. Özellikler yapının iç mekân düzeni ve malzeme bilgisi hakkında verilen bilgiler öngörüden öteye geçememiştir. Gümüşhane ilinin eğitim tarihi açısından büyük önem arz eden yapının, günümüze böyle metruk halde ulaşmış olması kültürel varlıklarımızın korunmasında bilinç yetersizliğinin tipik bir örneğini oluşturmaktadır.

Bina zemininde ve çevresinde yapılan saha gözlemleri ile okulun zemininde çökmeler meydana geldiği ve buna bağlı olarak zamanla çeşitli onarımlar geçirmek zorunda kaldığı gözlemlenmiştir.

Günümüze değin birçok onarım geçirdiği anlaşılan yapının 2021 yılında restorasyon çalışmalarına başlanmış olup, günümüzde ziyarete kapalıdır. Yapının restorasyon çalışmaları sonucunda; şehir arşiv ve kütüphanesi olarak kamu hizmetine devam ettirilmesi amaçlanmaktadır.

\section{Kaynakça}

Geçgil, S. (2016). Eski Gümüşhane (Süleymaniye Mahallesi) Metropolitlik Yapı Topluluğu Tarihsel Gelişimi ve Koruma Önerisi. (Yayımlanmamış yüksek lisans tezi). Yıldız Teknik Üniversitesi Fen Bilimleri Enstitüsü. İstanbul.

Boz, G. (Haz.). (2016). Gümüşhane Kültür Envanteri. Gümüşhane İl Kültür Turizm Müdürlüğü Yayınları, Gümüşhane.

Dolu. Y. Burak. (2010). Eski Gümüşhane (Süleymaniye Sit Alanı İçin Kentsel ve Yapısal Koruma Önerileri. (Yayımlanmamış Yüksek Lisans Tezi). İstanbul Teknik Üniversitesi Fen Bilimleri Enstitüsü.İstanbul.

Düzgün, E.-Çalı1k, İ. (2017). Gümüşhane İli Süleymaniye Mahallesindeki Tarihi Yapıların Sürdürülebilir Turizm Bağlamında Değerlendirilmesi.Erzincan Üniversitesi Sosyal Bilimler Enstitüsü Dergisi. Erzincan. 125-136.

Kolektif. (2019). Rum Ermeni Okulu Restitüsyon Raporu.Gümüşhane.

Sargın, S. ve Demir, Ş. (2018). İnsan Mekân İlişkisi Ölçeğinde Kent Kimliği ve Gümüşhane Örneği. The Journal of International Scientific Researches.3(4), 221-239.

Sözen. M. ve Tanyeli. U. (2014). Hartama.Sanat Kavram ve Terimleri Sözlüğü. İstanbul.130.

Sözen. M. ve Tanyeli. U. (2014). Çörten.Sanat Kavram ve Terimleri Sözlüğü. İstanbul.80.

URL-1:https://kulturenvanteri.com/yer/gumushane-rumlisesi/\#16/40.449272/39.454159, (E. T.: 21.09.2021 13.04).

URL-2:http://zsmimarlik.com/gumushane-rum-okulu.html. (E.T.:15.09.2021, 02.13) 